GEOGRAFICKÝ ČASOPIS / GEOGRAPHICAL JOURNAL 73 (2021) 1, 05-20

DOI: https://doi.org/10.31577/geogrcas.2021.73.1.01

\title{
STONE MOUNDS AND WALLS AS A RELICT OF TRADITIONAL VITICULTURAL LANDSCAPE (CASE STUDY MODRA AREA, SLOVAKIA)
}

\author{
Ján Hanušin*, Dagmar Štefunková**, Miloš Rusnák* \\ * Institute of Geography, Slovak Academy of Sciences, Štefánikova 49, 814 73, Bratislava, Slovakia, \\ hanusin@savba.sk, geogmilo@savba.sk \\ ** Institute of Landscape Ecology, Slovak Academy of Sciences, Štefánikova 3, P.O.Box 254, 81499 Bratislava, \\ Slovakia, dagmar.stefunkova@savba.sk
}

\begin{abstract}
Stone mounds and walls as a relict of traditional viticultural landscape (case study Modra area, Slovakia)

Stone mounds and walls are defined as the man-made accumulations of the unnecessary skeletal material accumulated over centuries as by-products of vineyards cultivation usually at the borders of plots. Their distribution, position, shapes and volume are analyzed; the basic types are defined and causes of their disappearance and transformation are interpreted relying on the comparison of situations in 1894 and 2018. A combination of the historical maps, aerial images and Lidar data study and field research as well were used for the identification and analysis of stone mounds and walls. The volumes of stone mounds and walls in 2018 were computed from the digital terrain model derived from the Lidar data. Dependencies between the individual characteristics in individual years were quantified by correlation coefficient $(r)$ and that of determination $\left(r^{2}\right)$. Compared to 1894, the number of stone mounds in 2018 decreased by $38 \%$, their overall area diminished by $62 \%$. The main driving force of the disappearance or transformation of stone mounds and walls has been the transition to large-area vineyards. Stone mounds and walls though remain a noticeable testimony to the traditional viticultural landscape with undeniable biodiversity and cultural/ historical value.
\end{abstract}

Key words: stone mounds and walls, traditional viticultural landscape, Lidar data, Modra, Slovakia

\section{INTRODUCTION}

The shape, genesis, age, and purpose of stone accumulations in the landscape vary. Many of them have been accumulated for funeral purposes (e. g. prehistoric burial cairns) or are relics of medieval mining as e.g. the waste stone heaps (Šimůnek 2012 and Moore and Weiss 2016). An important part of stone mounds in varied forms and with different functions is associated with the farming landscape. In terms of shape or the arrangement of stones in the agricultural landscape the disarrayed ones in the form of a tossed stone deposit referred to as stone mounds or stone heaps are discerned (Moore and Weiss 2016, Dobrovodská et al. 2019, Duma et al. 2019 and Štefunková and Hanušin 2019), rock piles (Gage 2014 and Moore and Weiss 2016), dump walls (Gage 2014) or stone hedges i.e. obalas (Nyizsalovszki and Fórián 2007). Stone accumulations may fulfill the function of a deposit of unnecessary skeletal material, delimitation of plot boundaries, slope stabilization, or several functions simultaneously (Thorson 2002, Chartier 2006 and Gage 2014).

Stone lines and rock walls are types of field boundaries in a traditional agricultural landscape also including hedgerows, wooded enclosures, stone fences, etc. 
(Müller 2013). Although they probably existed locally starting during the Neolithic Age, arable field margins were widely established to mark field borders when the three-field crop rotation system was implemented at the beginning of medieval times (Poschlod and Braun-Reichert 2017). This development in Central Europe was rather postponed in accord with the decree of development of the economic and cultural society into the middle to late medieval age and it was associated with the reclaiming of unsettled areas during several colonization waves (Riezner 2007, Turcsányi 2009 and Migoń and Latocha 2018). Research and recordings of linear stone mounds and walls in the viticultural landscape are rather sporadic (e.g. Nyizsalovszki and Forian 2007 and Špulerova et al. 2017). Due to the considerably exposed relief, advanced organization of plots, and technology of the terrace construction in the oldest European viticultural areas stonewalled terraced structures prevail and have been mapped and assessed at a greater rate. (e. g. Sereni 1961, Petit et al. 2012, Tarolli et al. 2014, Varotto et al. 2019 and Rusterholz et al. 2020), and in Slovakia, for instance, by Štefunková and Hanušin (2019) and Slámová and Belčáková (2020).

Only indirect proofs of the beginning of stone walls making in the 13th century after the conclusion of the primeval division of the ownership of vineyards were found in the Little Carpathian vine growing area (Lukniš 1977). Thriving vineyards existed there already in the 14th century (Drábiková 1989) and the first written mention about the necessity to maintain regularly the vineyard walls in the Little Carpathian viticultural townlets is from the 16th century (Franko 2018).

The precise research of the age of stone mounds and walls is still fragmented in Europe; archaeological data is limited (e. g. Houfková et al. 2015). Research of field stone enclosures, as structures that comparatively well resist changes, confirms the occurrence of what is referred to as a meta-chronic landscape, where agricultural land use lasts from the prehistoric times until nowadays (Larsen 2016).

The stone mounds and stone walls, like hedgerows, may play an important role in the increase of the landscape's heterogeneity, connectivity, and biodiversity (Forman and Baudry 1984 and Poschlod and Braun-Reichert 2017), as well as its visual quality (de la Fuente de Val et al. 2006). The landscape's heterogeneity and visual quality in the area of the traditional viticulture with the occurrence of stone mounds, stone walls and stone walled terraces in the conditions of Slovakia were analyzed by Štefunková and Cebecauer (2006) and Štefunková and Hanušin (2019).

\section{AIM AND METHODOLOGY}

The aim of this paper is the comparative spatial analysis of the distribution of the stone mounds and walls and their characteristics, interpretation of causes of changes, and the basic typological division at the end of the 19th century (1894) and now (2018).

Different types of anthropogenic relief associated with viticulture, stone mounds, stone walls and stone walled terraces linked to traditional vine growing and modern bench terraces with their origin in the socialist period were found in the study area. Research concentrated on the stone mounds and walls, which are in terms of frequency of occurrence and the volume of accumulated skeletal material, an important trace demonstrating the transformation of the viticultural landscape since the medieval age till the middle of the 20th century. Stone mounds are 
mostly elongated, in some cases with a concentrated footprint. The trace of a stone mound is often irregular, rising and falling in height and width. Stone walls unlike stone mounds are not freely deposited, they are built, and their shape is regular, as the height and width are rather steady. Stone mounds distinctly prevail in the study area while the stone walls are infrequent.

Distribution of the majority of stone mounds and walls, in 1894 was acquired from the map of the Stable Cadastre (scale 1:2,880) where they are marked by the Hungarian word $k \ddot{o}$ (stone). After the analysis of the shape and after the assessment in the field, the periglacial hills, as the natural geomorphological bodies, were excluded from the marked objects. Analysis of the areal images, Lidar data and field research resulted in the identification of more than 50 stone mounds which were not, because they were in a forested area, recorded in the time of the Stable Cadastre mapping. This was how the 1894 database of stone mounds was complemented. The present situation in the distribution of stone mounds was obtained by a combination of several sources. The basis was their distribution on the 1:5,000 maps from 2010 (Derived State Map), aerial images from 2017 and field research when, along with visual reconnaissance, the end points of accessible stone mounds were localised by means of GPS during the period without vegetation. Final precision of the current status was done by means of the Lidar data when the stone mounds and walls or their parts lower than $0.4 \mathrm{~m}$ compared to the surrounding terrain were excluded by applying the Arc GIS 3D Analyst to the analysis of profiles of diagrams. Visual interpretation was assessed based on the RRIM (Red Relief Image Map) composed of the digital terrain model with $1 \mathrm{~m}$ resolution. Length, the maximal, minimal, and mean sea level altitude, the difference between the maximal and the minimal sea level altitude, mean inclination and mean aspects were set for each stone mound. From the shape of the ground plan three ground plan types were determined: elongated ellipsoid simple (ES), elongated compound (EC) and other (O) which includes other ground plan shapes (oval, rectangle, triangle, trapezoid, etc.). Stone mounds were localized, their area computed in relation to the basic geomorphological units after Mazúr and Lukniš (1978) (Podmalokarpatská pahorkatina Hills and the Homolské Karpaty Mts.) and within them to the basic geomorphological forms as defined by Urbánek (2014), that is, the valleys, hillsides, and plains along with the fault slopes, and periglacial hills. Volumes of stone mounds and walls in 2018 were computed from the digital terrain model (DTM) with a $0.5 \mathrm{~m}$ resolution, which was generated from the Lidar classified point cloud obtained from the Geodesy, Cartography and Cadastre Authority of the SR. Individual vectorized stone mounds and walls were converted into a raster format with a $0.5 \mathrm{~m}$ resolution. In the Raster Calculator (ESRI ArcGIS) with a CON function all existed stone mounds and walls were removed from the DTM and replaced by no data values (Null). Subsequently, the "elevation void fill" function was used for the interpolation of the terrain voids of stone mounds and walls for the creation of the DTMnull model without these features. This terrain represents an approximated terrain which theoretically reflects the state of the relief before the material of stone mounds was deposited. In the following calculations the effect of the real relief which was originally below the accumulations was omitted. The resulting calculation of the volume of stone mounds and walls was accomplished based on the DTM, a DTMnull raster difference in the ArcGIS using the "cut fill" function. Regarding the disharmony in the shape of the relief in a great part of the study area in 1894 and at present (relief obtained from Lidar), affected by the construction of the 
terraced vineyards and other new build-up areas, the volume of stone mounds and walls in 1894 was not assessed. The volume calculated in this manner does not reflect the natural porosity of stone mounds and walls. No probes, uncovering or analysis of their inner parts were done in this phase of research. Dependencies between the individual characteristics (excluding the ground plan type) in the two tracked years were quantified by the correlation coefficient $(r)$ and determination coefficient $\left(r^{2}\right)$ for which the values for the $99 \%$ limit of the reliability after Pavlík and Kühnl (1981) (for $r$ ) and after Cohen (1992) (for $r^{2}$ ) were set. All other parameters except for the area and type were obtained from the DTM in the ArcGIS 10.0.

\section{CHARACTERISTICS OF THE TERRITORY AND THE DEVELOPMENT OF VITICULTURAL LANDSCAPE}

The study area (707 ha) covers the south-west central part of the Modra cadastre, west from its inner urban area on the contact zone between the south-eastern slopes of the Little Carpathians Mountains (Homolské Karpaty) and the submountain hill land (Podmalokarpatská pahorkatina), some $17 \mathrm{~km}$ north-east of Bratislava's suburbs (Fig. 1).

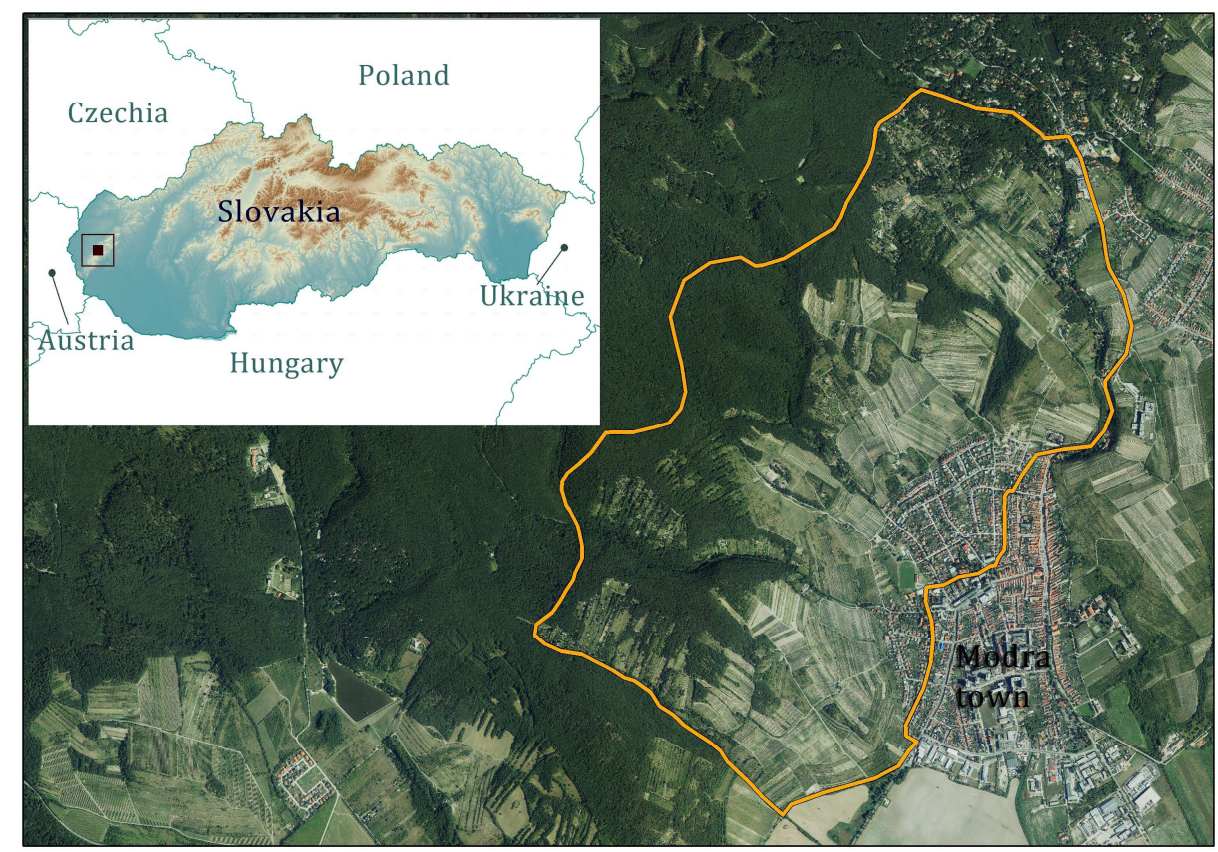

Fig. 1. The study area

The first mention of vineyards in the Little Carpathians dates back to the 13th and 14th centuries and vine production experienced its greatest boom in the 16th and 17 th centuries while it remained the most significant economic activity in this region at the end of 19 th and the beginning of the 20th centuries (Turcsány 2006). The study area contains the forests of the Little Carpathians in the north, agricultural areas consisting of the mosaic of grassland, gardens, vineyards, wood vegeta- 
tion, and areas of holiday housing. Intensively used terraced and not terraced vineyards owing their origin to the process of the socialist collectivisation in the second half of the 20th century are next to the south-eastern boundary of the territory. In the north there is an urban part Harmónia with a dense built-up area of prevailing recreation facilities. Altitudes vary from $153 \mathrm{~m}$ to $373 \mathrm{~m}$ a. s. 1. Specific geomorphological bodies are the periglacial hills, i.e. the natural protuberances of the bedrock modified by the exogenous processes. They are quite common first of all in the top planate parts of the Little Carpathians but also in lower less dissected places at the foothills of the Podmalokarpatská Pahorkatina Hill (Lukniš 1977 and Urbánek 2014). Granites and similar rocks dominate in geological composition as the prevailing rocks in the whole study area. Sandy-loamy soils prevail in the southern part of the territory while in the smaller northern part there are loamy-sandy soils; the content of the skeletal material in the soils in the north is over $25 \%$, while in the remaining parts it is $10-25 \%$ (Pospíšilová et al. 2005) classifying these soils between the scarcely to moderately skeletal soils in Slovakia (Śály 1996). There is no well-developed permanent river system and the loamy-sand Cambisols prevail in the soil cover (Ś́ly and Šurina 2002), which has been converted into Anthrosols by the regular vineyard cultivation and terracing. The climate is moderately warm and dry, with a mean annual temperature above $9^{\circ} \mathrm{C}$ and an average annual precipitation between $550 \mathrm{~mm}$ and $600 \mathrm{~mm}$ (Lapin et al. 2002).

Only island residues of the original oak-hornbeam Carpathian forests, oak and Turkey - oak forest associations have survived from the original forest associations which covered the area before human interventions in the landscape (Maglocký 2002). The long-time neglected maintenance of the walls caused them to be overgrown by wood species with a composition close to the original oak-hornbeam, hornbeam or Turkey oak and oak woods. Invasive species and ruderal species are also spread in the vegetation cover of the stone walls (Štefunková et al. 2011).

\section{RESULTS}

Stone mounds and walls as accumulations of unnecessary stone material are logically concentrated in areas with a potential abundance of such material, that is, inclined and dissected positions with shallow soils and a high content of skeletal material, which was in the study area in the Homolské Karpaty Mts. The stone material of the mounds consists almost exclusively of sharp-edged granitoid blocks. Stones with elongated shape are typical for the $20-70 \mathrm{~cm}$ size of the longer side and $10-30 \mathrm{~cm}$ of the shorter side. Larger blocks are rather rare. The cross-section of a stone mound is mostly asymmetrically triangular, trapezoid or semi-circular. Asymmetry of the cross-section is often caused by the horizontal curvature of the terrain or by the position of the stone mound on a terrain edge usually on the margin of the former vineyard. The purpose of this type of stone mounds in some places was the support of the slope. The distances between the individual parallel stone mounds in places with the highest density are $25-40 \mathrm{~m}$, seldom less. The height of stone mounds oscillates from several tens of centimetres up to $4 \mathrm{~m}$; the width is $2-20 \mathrm{~m}$; the length of the ES type is between 5 to $460 \mathrm{~m}$, while the biggest and branched stone mound of EC type identified in 1894 measured a total of $760 \mathrm{~m}$ (Fig 2a). The proportion of stone mounds with a relatively homogenous shape is estimated at about $30-40 \%$. The height of stone walls is below $1.0-1.5$ $\mathrm{m}$; the width is $1-5 \mathrm{~m}$, and the symmetrical almost rectangular cross-section is relatively steady (Fig. 2b). Both mounds and walls are mostly oriented to the south- 
east and south-west which agrees with the optimal orientation of vineyards in this region (Braun and Vanek 1985).
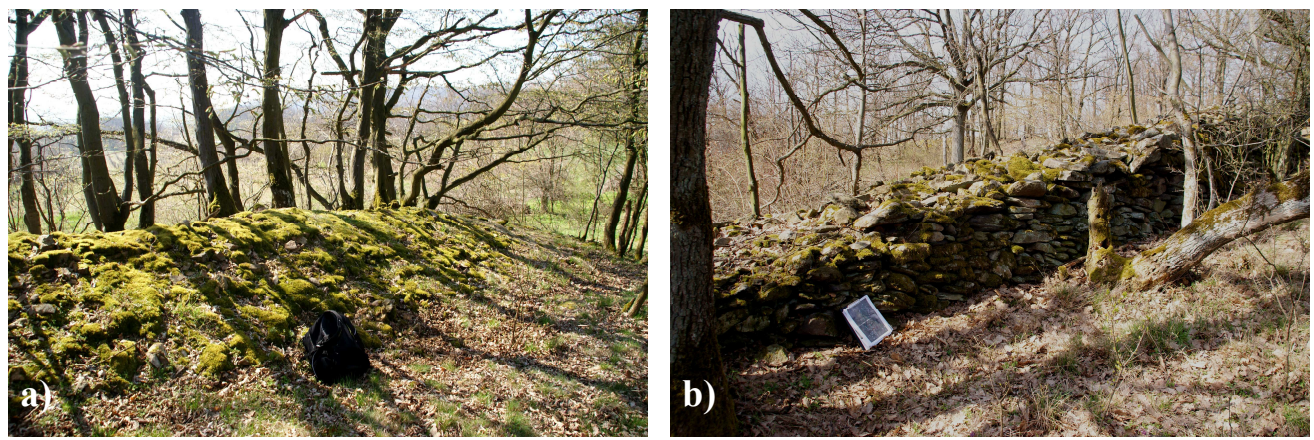

Fig. 2. Examples of typical stone mound (a) and stone wall (b)

Regarding the scope of the accumulated material it is supposed that the stone mounds were built over tens even hundreds of years. They are also found on the map of the Stable Cadastre from 1894 in the localities immediately neighbouring with the historical built-up areas (most of them are in the north-western part of what is today the inner urban area) where one of the oldest vineyards of Modra supposedly existed along with the very first stone mounds whose origin temporarily agrees with the beginnings of viticulture in Modra in the 13th -14 th century. Later, especially in the 16th and 17th century, in a time of high prosperity and the largest extension of the vineyards in the Modra area, stone mounds and walls were also built in remote parts up to a 2,800 m distance from the town centre. The elevation of the most elevated stone mounds relative to the town centre is almost 190 metres (Figs. 3a and 3b).
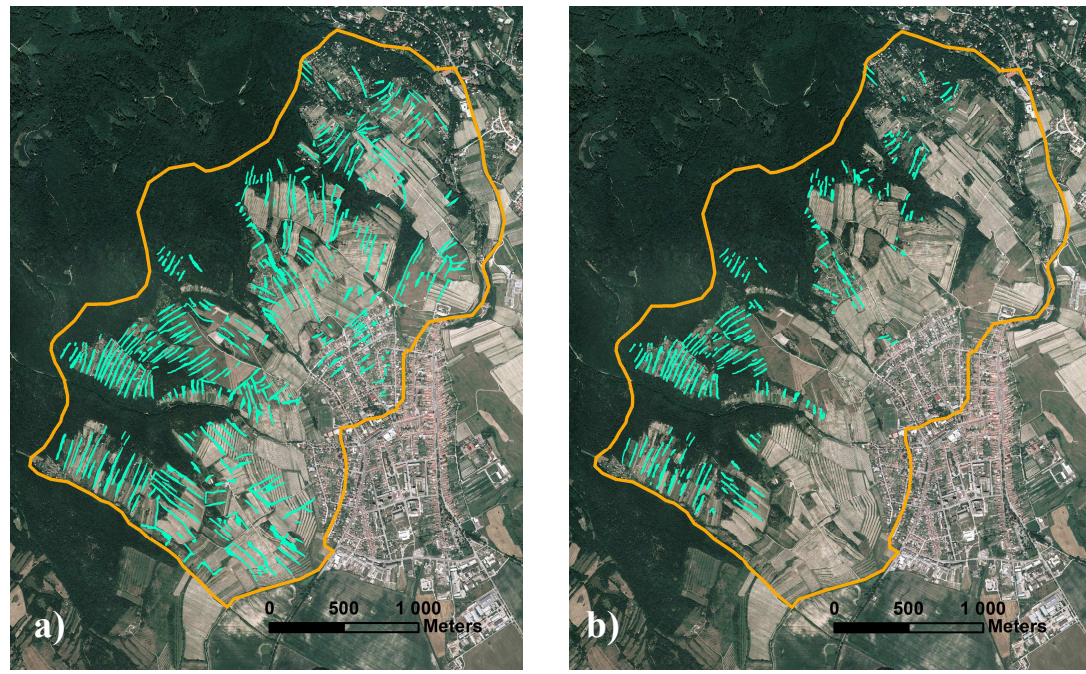

Fig. 3. Stone mounds distribution a) - in 1894, b) - in 2018 
The results reveal important changes in the scope, size, and shape of stone mounds in time (between the studied years) and in space (differences between the Podmalokarpatská Pahorkatina hill and the Homolské Karpaty mts.). The building of terraced vineyards and an extension of the built-up area were the cause why the stone mounds and walls in lower situated positions of the Podmalokarpatská Pahorkatina Hill were removed. Stone mounds and walls in higher and more dissected positions on the margin of the belt of vineyards and in the forest (former vineyards) did no substantially change. Compared to 1894, the number of stone mounds and walls in 2018 dropped by $38 \%$; their overall area diminished by $62 \%$; the mean area diminished by $40 \%$ and their mean length dropped by $42 \%$. On the contrary, the mean altitude a. s. 1 . increased (by 10\%) and so did the mean inclination (by about 20\%) - Fig. $4 \mathrm{a}-\mathrm{d}$ ).
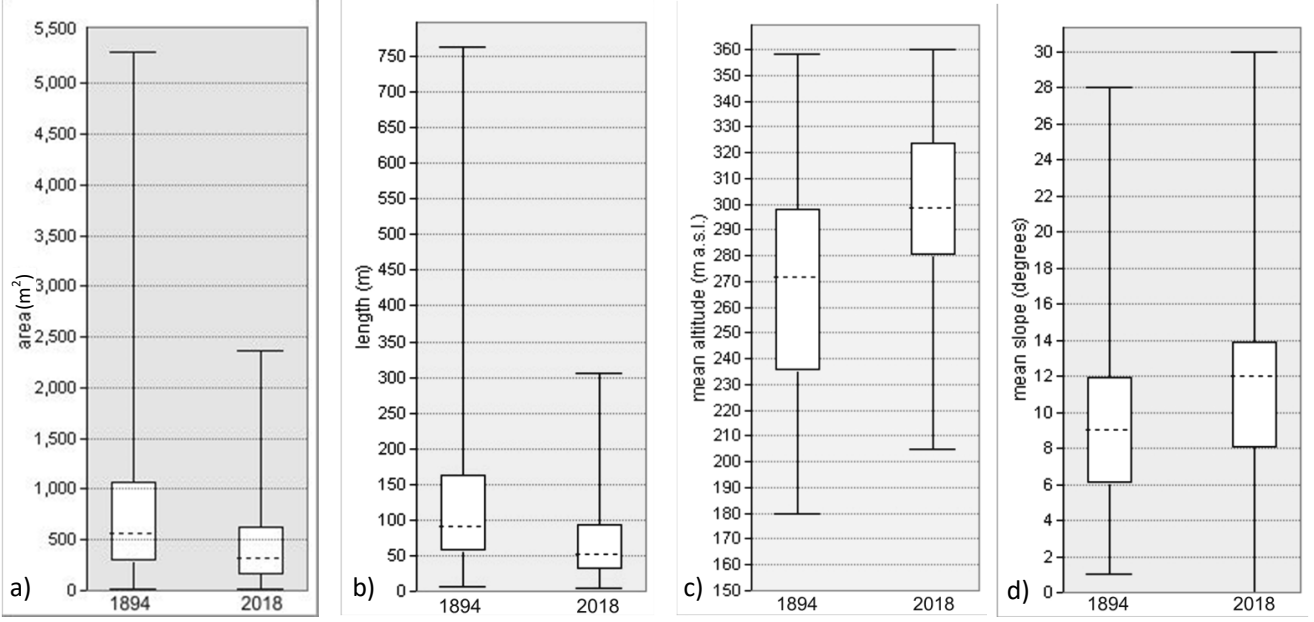

Fig. 4. Stone mounds and walls characteristics

a) - area, b) - length, c) - mean altitude, d) - mean slope

The main driving forces of removal or transformation of stone mounds and walls were the origin of large-scale vineyards (removal of about 110 stone mounds), urbanization in the inner urban area of Modra (removal of 24 stone mounds) and partially increased suburban construction of recreational buildings in Harmónia (removal of 10 stone mounds). Transformation of vineyards into largescale ones took place mostly in the lower situated, less dissected and more accessible Podmalokarpatská Pahorkatina Hill along with the process of the urban sprawl. The density of stone mounds and walls (expressed as an area in $\mathrm{m}^{2}$ per 1 ha) was greatest in the Homolské Karpaty Mts. in 1894 on the hillsides and fault slopes; this order swapped in 2018. The most typical ground plan shape of stone mounds is an elongated ellipsoid simple type (ES) which definitely dominates in the number of stone mounds $(83 \%$ of stone mounds in $1894,93 \%$ in 2018$)$ and their area $(75 \%$ in $1984,94 \%$ in 2018). The elongated composed type (EC) amounted to almost a quarter of the area of stone mounds in 1894 and it was the one most affected by removal and transformation of stone mounds so that its area was only about $4 \%$ in 2018. Characteristics of the individual types of stone mounds and walls are presented in Tab. 1. 
Tab. 1. Characteristics of the individual types of stone mounds and walls (ground plan shape: ES - elongated ellipsoid simple, EC - elongated compound, O - other shapes, ND - no data)

\begin{tabular}{rcrccccccc}
\hline Year & $\begin{array}{c}\text { Stone } \\
\text { mound } \\
\text { type }\end{array}$ & $\begin{array}{c}\text { Number } \\
\text { of mounds }\end{array}$ & $\begin{array}{c}\text { Total } \\
\text { area (ha) }\end{array}$ & $\begin{array}{c}\text { Mean } \\
\text { area (ha) }\end{array}$ & $\begin{array}{c}\text { Mean } \\
\text { altitude } \\
(\mathrm{m} \text { a.s.l. })\end{array}$ & $\begin{array}{c}\text { Mean } \\
\text { slope } \\
(\text { deg. })\end{array}$ & $\begin{array}{c}\text { Mean } \\
\text { aspect }\end{array}$ & $\begin{array}{c}\text { Mean } \\
\text { volume } \\
\left(\mathrm{m}^{3}\right)\end{array}$ & $\begin{array}{c}\text { Mean } \\
\text { length } \\
(\mathrm{m})\end{array}$ \\
\hline 1894 & ES & 303 & 22.60 & 0.07 & 274 & 9.8 & 147 & ND & 116 \\
& EC & 45 & 7.20 & 0.16 & 238 & 8.3 & 135 & ND & 210 \\
& O & 17 & 0.33 & 0.19 & 261 & 9.1 & 127 & ND & 23 \\
\hline 2018 & ES & 211 & 10.40 & 0.05 & 298 & 11.1 & 158 & 426 & 73 \\
& EC & 5 & 0.48 & 0.09 & 306 & 12.6 & 163 & 922 & 122 \\
& O & 10 & 0.25 & 0.025 & 291 & 9.5 & 168 & 274 & 23 \\
\hline
\end{tabular}

The majority of stone mounds and walls or their parts of all ground plan types were in both geomorphological units and in both years on the hillsides. Considerably fewer of them were on fault slopes. Type $\mathrm{O}$ was only identified on the hillsides in both years. EC type stone mounds in 1894 were approximately equally also distributed on the plains. In 1894 the area of EC and ES types on the Podmalokarpatská Pahorkatina Hill were relatively even (area of type EC was here $86 \%$ of the area of type ES).

Analysis of the statistical significance of the dependencies between individual characteristics of stone mounds and walls by the correlation coefficient $(r)$ and determination coefficient $\left(r^{2}\right)$ proved significant values of $r$ and $r^{2}$ for the logical dependencies ensuing from the size and morphological properties and the position of stone mounds and walls in a more inclined terrain (for instance, the dependence between the area and volume, length, elevation, and inclination differences). Other values of $r$ and $r^{2}$ showed that stone mounds and walls situated in higher altitudes are oriented mostly to the north-east or south-east. Likewise, the positive correlation between the inclination and volume of stone mounds and walls in 2018 was observed. It means that stone mounds and walls on more inclined positions were more voluminous. Analyses did not confirm dependences between the mean sea level altitude, inclination, and aspect on the one side and the area (for 2018) or length of stone mounds on the other.

\section{DISCUSSION}

One of the principal methodological problems of the research was the identification and delimitation of exact boundaries (of the shape) of stone mounds and walls. As Duma et al. (2019) report, reaching this objective requires a combination of several methods. In this case four basic methods were applied: analysis of several cartographic sources, aerial images, Lidar data and field research (visual assessment and partial GPS localization). Although Karlík et al. (2017) applied new semi -automated remote sensing methods of modern vineyard localization in the Modra cadastre, we did not apply them in the studied area, as our primary goal was to identify stone walls and mounds. These relief forms were originally associated mainly with traditional vineyards, today we can find them in various landcover types (forests, pastures, agricultural mosaics and vineyards). Stone walls and 
mounds only marginally interfere with modern vineyards, which are, on the contrary, a suitable object for use of the mentioned innovative approaches.

The ground plan shape of stone mounds on the maps of the Stable Cadastre from 1894 was marked schematically usually with sharp endings. Based on the assessment of the present state of the preserved stone mounds these shapes are not taken for real in the majority of cases. Several authors (e. g. Kaim et al. 2014 and Forejt et al. 2018) drew attention to the ambiguity of land use interpretation from old maps. Supposedly in some cases the shape and size of periglacial hills were modified by anthropogenic accumulation of stones from vineyards, so their distinction from the typical stone mounds is not quite reliable. The precise distinction is practically impossible because of the homogeneity of the stone material in the study area.

The Lidar based DTM is a useful but not universal and conclusive tool for the identification of shapes in the landscape (Hofierka et al. 2018 and Dušeková et al. 2020). As Mlekuž (2013) reports, the Lidar record captures all the "mess of humps and bumps" in the terrain regardless of their origin, properties, age, purpose, etc. making necessary the interpretation of researched shapes by other methods. Stone mounds and walls in the study area are mostly well discernible from its surrounddings but they are not unambiguously and clearly different on the precise digital models, as they can be confused with the edges and slopes of the terraced vineyards (Fig. 5).
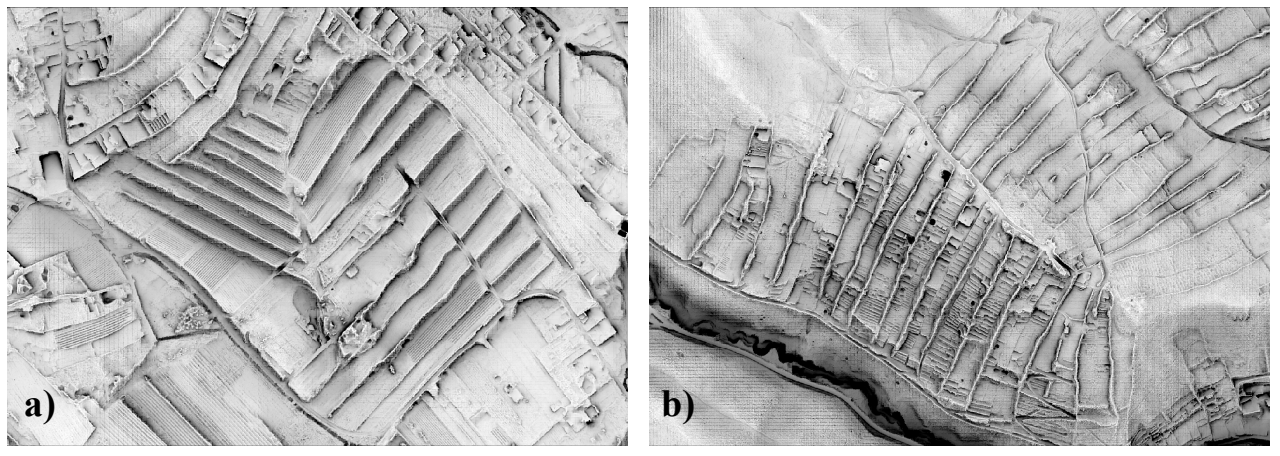

Fig. 5. Comparison images of Positive Topographic Openness model generated form the DTM Lidar in the areas where elongated shapes represent a) - terraced vineyards and b) - stone mounds and walls

In case of ambiguous interpretation the shape was analyzed in the $3 \mathrm{D}$ Analyst ARC GIS applying the interpolate line - a profile graph tool with occasional verification in the terrain.

The basic errors that occur in the calculation of the volume of stone mounds and walls are associated with the interpolation of the theoretical surface of the terrain which is based on a simple linear interpolation of surface between the outer edges of stone mounds and walls. However, in fact this surface does not reflect the real terrain which was there before the terrain adjustments and construction of terraces.

Only indirect dating of the period when the stone mounds and walls first appeared is possible by analyzing historical records and old maps. The oldest stone 
mounds and walls in Modra have probably developed in the close vicinity of the town's inner urban area with the beginnings of the local viticulture in the 13th and the 14th century and gradually expanded to more remote parts. The origin of the most remote stone features out of the urban area is dated in the period of peaking prosperity and the scope of the local vineyards in the 16th and 17th centuries when the vineyards (and stone mounds and walls) were made as far as 2,800 m from the town centre. But the maps of the 1st Ordinance Survey from $1782-1784$, that is, more than 100 years later show the forest border draw closer to the town some $1,800-2,100 \mathrm{~m}$ away, i. e. part of the vineyards most distant from the town was abandoned and gradually afforested. Due to this fact, the origin of stone mounds can be dated to the 14 th -17 th century supposing that the dynamism of increase of their size (volume) corresponds to the overall expansion trend of the vineyards.

The overall volume of stone mounds calculated for the year 2018 was about $100,000 \mathrm{~m}^{3}$ (Fig. 6). Simplified analogy relying on the number of stone mounds makes it possible to estimate their volume in 1894 at about $160,000 \mathrm{~m}^{3}$. The quoted volumes have been calculated for a hypothetical situation counting on $100 \%$ filled stone mounds, which is not possible. For the stone walls in Connecticut, USA, the volume of space not filled by stones (porosity) is reported at $11 \%$ (Johnson and Ouimet 2016), and the document of the Council of Europe (2019) quotes 25\%. If the low rate of arrangement of stone material in stone mounds in the study area is taken into consideration, the probable porosity is $20-25 \%$. Subsequently, the net volume of the accumulated stone material can be estimated at $120-128$ thousand $\mathrm{m}^{3}$ in 1894 and $70-75$ thousand $\mathrm{m}^{3}$ nowadays. The density of stone mounds in the study area $\left(6.3 \mathrm{~km} / \mathrm{km}^{-2}\right.$ in 1894 or $2.2 \mathrm{~km} . \mathrm{km}^{-2}$ nowadays $)$ is similar to that in the Polish Jizerské Hory Mts. (2.2 km/ $\mathrm{km}^{-2}$, Duma et al. 2019), but distinctly lower than the mean density of $12 \mathrm{~km} / \mathrm{km}^{-2}$ reported in New England by Johnson and Ouimet (2016).

Cross-cuts and dimensions of stone mounds in the study area are now generally similar to those quoted for the stone mounds in the Polish Jizerské Hory Mountains, that is, a triangular or rectangular cross-cut with the maximal length below $418 \mathrm{~m}$, height below $4.5 \mathrm{~m}$, and the width below $7 \mathrm{~m}$ (Duma et al. 2019). However, in 1894, there were in the study area numerous EC type stone mounds longer than $500 \mathrm{~m}$. Duma et al. (2019) do not quote the volume of the stone mounds. Considerably smaller dimensions are those of the New England stone walls in the northeast of the USA reported by Johnson and Ouimet (2016) (height below $1.4 \mathrm{~m}$, width below $2.5 \mathrm{~m}$ ). Thorson (2005) reports the $1.4 \mathrm{~m}$ height as a maximal one for hand depositing considering the "humans' optimal strength", which is the optimal height for an adult individual to carry a load (stones). The height/width of stone walls of $1.4 / 5-6 \mathrm{~m}$ and $2-3 / 20 \mathrm{~m}$ height/width for stone mounds (heaps) was observed in the Polish Sudeten (Latocha 2012); the $3-4 \mathrm{~m}$ width and $2-3 \mathrm{~m}$ height of stone hedges was observed in the Tokai area in Hungary (Nyizsalovszki and Fórián 2007).

The rest of the old cultural landscape (small natural features - SNF) - Hunter (2017) increase the heterogeneity and thus the biodiversity of agricultural landscape (Benton et al. 2003 and Weibull et al. 2003). Stone mounds and walls in the study area are the only significant element of the SNF. According to Kleyer (1991 in Poschlod and Braun-Reichert 2017), the SNF cover $4-6 \%$ of the overall area of intensively used agricultural landscape and below $11 \%$ of a less intensively used agricultural landscape. On the Podmalokarpatská Pahorkatina Hill, land covered by 
SNF (in this case stone mounds), in 1894 was about 4\% and in 2018 only about $0.3 \%$ of the area which is a lot less than the values presented by Kleyer (1991).

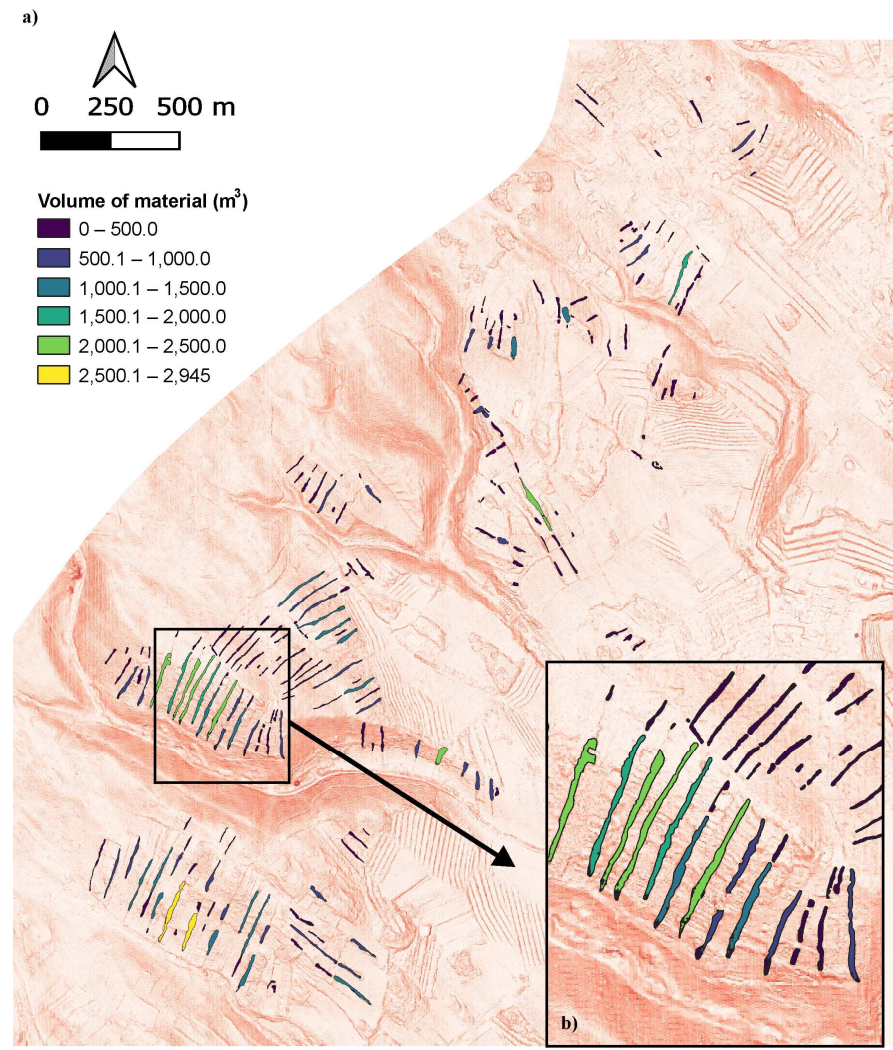

Fig. 6. Spatial distribution of stone mounds and walls overall volumes calculated for the year 2018 from Lidar data (a) and detail to volume material from Fig. 5b (b).

Base layer of RRIM (Red Relief Image Map) were derived from Lidar data of Geodesy, Cartography and Cadastre Authority of the SR.

Stones in stone mounds and walls and the space between them are gradually filled with dust, settled by bacteria, later by moss, lichens, and fungi followed by their disintegration resulting in an organic substrate for higher plants, insects and other fauna (Council of Europe 2019). The positive significance of stone walls for the biodiversity was confirmed by research (Manenti 2014 and Council of Europe 2019). Another important function of stone mounds is their cultural and historical value as a testimony to the development and existence of a traditional viticultural landscape. The Council of Europe (2019) has treated the theme and justified the conservation of stone mounds and walls. The document recommends the necessity to know, to protect, and maintain the dry-stone structures in the landscape in order to prevent their disappearance, decline of biodiversity, and the loss of cultural values. The importance of areas with a preserved historical viticultural structure in the southwestern part of the studied area with the highest density of stone mounds and walls is also emphasized by the Local Territorial System of Ecological Stabi- 
lity of Modra (Š́mová et al. 1996) which is an obligatory document of ecological regulations for planning processes in the landscape and decision-making activities of public administration bodies.

\section{CONCLUSION}

Stone mounds and walls in a viticultural region as the representatives of noticeable forms of anthropogenic relief are studied and analyzed in this paper. They have been scarcely treated as a research subject in the specialized literature in the Central European space. Seen from the narrow focused pragmatic angle of modern viticulture, stone mounds and walls are not an active or necessary component of the viticultural landscape, they are rather barriers. Analysis of stone mounds and walls distribution, their characteristics and calculation of their volume is a possible contribution of the study. In spite of the advantages and positive properties, the Lidar data alone without the application of the combination of cartographic and field data is not sufficient for the precise delimitation of the position and shape of stone mounds and walls.

Stone mounds and walls of Modra remain a witnesses to the local viticultural landscape with an undoubted biodiversity and cultural-historical value in spite of the reduction they suffered during the construction of the modern vineyards in the 1970s. These are the reasons why the best conserved and the most typical part of the area with stone mounds and walls deserves renovation, protection, and also adequate presentation after the revitalisation of the traditional vine growing landscape and possibly in the form of an educational path.

This paper was prepared within the project of the Scientific Grant Agency of the Ministry of Education, Science, Research and Sport of the Slovak Republic and the Slovak Academy of Sciences VEGA No. 2/0013/18 Evaluation of the transformation of natural and socio-cultural diversity of the cultural landscape in Slovakia (on example of selected areas).

\section{REFERENCES}

BENTON, T. G., VICKERY, J. A.,WILSON, J. D. (2003). Farmland biodiversity: Is habitat heterogeneity the key? Trends in Ecology \& Evolution, 18, 182-188. DOI: https// doi.org/10.1016/S0169-5347(03)00011-9.

BRAUN, J., VANEK, G. (1985). Pestujeme vinič. Bratislava (Príroda).

COHEN, J. (1992). A power primer. Psychological Bulletin, 112, 155-159.

Council of Europe, European Landscape Convention 10th council of Europe conference on the European Landscape Convention (2019). Council contributing to the implementation of the European Landscape Convention of the Council of Europe - Dry stone in the landscape, ancestral and innovative, for sustainable territories, [Online]. Available: https://rm.coe.int/council-of-europe-european-landscape-convention-10th-council-ofeurope/168096844b [Accessed 24 August 2020].

De la FUENTE De VAL, G., ATAURI, J. A., De LUCIO, J. V. (2006). Relationship between landscape visual attributes and spatial pattern indices: A test study in Mediterranean-climate landscape. Landscape and Urban Planning, 77, 393-407. DOI: https:// doi.org/10.1016/j.landurbplan.2005.05.003.

DOBROVODSKÁ, M., KANKA, R., DAVID, S., KOLLÁR, J., ŠPULEROVÁ, J., ŠTEFUNKOVÁ, D., MOJSES, M., PETROVIČ, F., KRIŠTÍN, A., STAŠIOV, S., HALADA, L., GAJDOS, P. (2019). Assessment of the biocultural value of traditional agricultural landscape on a plot-by-plot level: Case studies from Slovakia. Biodiversity and Conservation, 28, 2615-2645. DOI: https://doi.org/10.1007/s10531-019-01784-X. 
DRÁBIKOVÁ, E. (1989). Človek vo vinici. Bratislava (Veda).

DUŠEKOVÁ, L., LAČNÝ, A., VESELSKÝ, M., PAPCOO, J., ŠUJAN, M. (2020). Lidarové dáta pri výskume závrtov na plošinách kuchynsko-orešanského krasu. Geografický časopis, 72, 371-390. DOI: https://doi.org/10.31577/geogrcas.2020.72.4.00.

DUMA, P., LATOCHA, A., ŁUCZAK, A., PIEKALSKI, J. (2019). Stone walls as a characteristic feature of the cultural landscape of the Izera Mountains, southwestern Poland. International Journal of Historical Archaeology, 24, 22-43. DOI: https:// doi.org/10.1007/s10761-019-00501-2.

FOREJT, M., DOLEJŠ, M., RAŠKA, P. (2018). How reliable is my historical land-use reconstruction? Assessing uncertainties in old cadastral maps. Ecological Indicators, 94, 237-245. DOI: https://doi.org/10.1016/j.ecolind.2018.06.053.

FORMAN, R. T. T., BAUDRY, J. (1984). Hedgerows and hedgerow network in landscape ecology. Environmental Management, 8, 499-510.

FRANKO, M. (2018). Organizácia a správa viničných hôr malokarpatských miest Svätý Jur, Pezinok a Modra (druhá polovica 16. storočia a 17. storočie). Trnava (Trnavská univerzita).

GAGE, J. E. (2014). Field clearing: Stone removal and disposal practices. Agriculture \& Farming, Bulletin of the Archaeological Society of Connecticut, 76, 33-81.

HOFIERKA, J., GALLAY, M. A, BANDURA, P., ŠAŠAK, J. (2018). Identification of karst sinkholes in a forested karst landscape using airborne laser scanning data and water flow analysis. Geomorphology, 308, 265-277. DOI: https://doi.org/10.1016/ j.geomorph.2018.02.004.

HOUFKOVÁ, P., BUMERL, J., POSPÍŠIL, L., KARLÍK, P., BENEŠ, J., BERNARDOVÁ, A., HRABALÍKOVÂ, M., JANEČKOVÁ-MOLNẢROVÁ, K., HEJCMAN, M. (2015). Origin and development of long-strip field patterns: A case study of an abandoned medieval village in the Czech Republic. Catena, 135, 8391. DOI: https:// doi.org/10.1016/j.catena.2015.06.017.

HUNTER, M. (2017). Conserving small natural features with large ecological roles: An introduction and definition. Biological Conservation, 211, 1-2. DOI: https:// doi.org/10.1016/j.biocon.2016.12.019.

CHARTIER, C. S. (2006). Stone walls and stone piles at Saw Mill Pond, Easton, Massachusetts: An intensive archaeological survey. Plymouth Archaeological Rediscovery Project, [Online]. Available: https://plymoutharch.com/wp-content/uploads/2014/11/ easton-piles.pdf [Accessed 2 December 2020].

JOHNSON, K. J., OUIMET, W. B. (2016). Physical properties and spatial controls of stone walls in the northeastern USA: Implications for Anthropocene studies of 17th to early 20th century agriculture. Anthropocene, 15, 22-36. DOI: https://doi.org/10.1016/ j.ancene.2016.07.001.

KAIM, D., KOZAK, J., OSTAFIN, K., DOBOSZ, M., OSTAPOWICZ, K., KOLECKA, N., GIMMI, U. (2014). Uncertainty in historical land-use reconstructions with topographic maps. Quaestiones Geographicae, 33(3), 55-63. DOI: https://doi.org/10.2478/ quageo-2014-0029.

KARLIK, L., GÁBOR, M., FALŤAN, V., LAUKO, V. (2017). Monitoring využívania vinohradníckych plôch: prípadová štúdia Modra (Slovensko), Geographia Cassoviensis, $11,22-32$.

KLEYER, M. (1991). Die Vegetation linienförmiger Kleinstrukturen in Beziehung zur landwirtschaftlichen Produktionsintensität. Dissertationes Botanicae, 169. Berlin, Stuttgard (Cramer).

LAPIN, M., FAŠKO, P., MELO, M., ŠŤASTNÝ, P., TOMLAIN, J. (2002). Klimatické oblasti. Mapa 1:1 000 000. Atlas krajiny Slovenskej republiky. Bratislava (Ministerstvo životného prostredia Slovenskej republiky, Esprit, s. r. o.).

LARSEN, J. (2016). Archaeological investigations of an agrarian landscape in western Norway - the fjord farm Indre Matre. In Klápště, J., ed. Agrarian technology in the medieval landscape. Turnhout (Brepols), pp. 185-194. DOI: https://doi.org/10.1484/ M.RURALIA-EB.5.110464. 
LATOCHA, A. (2012). Przemiany społeczno-gospodarcze i przyrodnicze doliny Dzikiej Orlicy w okresie powojennym. Orlické Hory a Podorlicko, 19, 85-106.

LUKNIS, M. (1977). Geografia krajiny Jura pri Bratislave. Bratislava (Univerzita Komenského).

MAGLOCKÝ, Ś. (2002). Potenciálna prirodzená vegetácia. Mapa 1:500 000. Atlas krajiny Slovenskej republiky. Bratislava (Ministerstvo životného prostredia Slovenskej republiky, Esprit, s. r. o.).

MANENTI, R. (2014). Dry stone walls favour biodiversity: A case-study from the Apennines. Biodiversity and Conservation, 23, 1879-1893.

MAZÚR, E., LUKNIŠ, M. (1978). Regionálne geomorfologické členenie SSR. Geografický časopis, 30, 101-125.

MIGON, P., LATOCHA, A. (2018). Human impact and geomorphic change through time in the Sudetes. Central Europe. Quaternary International, 470 (A), 194-206. DOI: https://doi.org/10.1016/j.quaint.2018.01.038.

MLEKUŽ, D. ( 2013). Messy landscapes: Lidar and the practices of landscaping. In Opitz, R. S., Cowley, D. C., eds. Interpreting archaeological topography airborne laser scanning, 3D data and ground observation. Oxford, Oakville (Oxbow Books), pp. 88-99.

MOORE, C. M., WEISS, M. V. (2016). The continuing "Stone Mound Problem": Identifying and interpreting the ambiguous rock piles of the upper Ohio valley. Journal of Ohio Archaeology, 4, 39-71.

MÜLLER, G. (2013). Europe's field boundaries. Hedged banks / hedgerows / field walls (stonewalls) / dead brushwood hedges / bent over hedges /woven hedges / wattle fences / traditional wooden fences. Stuttgart (Neuer Kunstverlag).

NYIZSALOVSZKI, R., FORIÁN, T. (2007). Human impact on the landscapin in the Tokaj foothill region, Hungary. Geografia Fisica e Dinamica Quaternaria, 30, $219-224$.

PAVLÍK, Z., KÜHNL, K. (1981). Úvod do kvantitativnich metod pro geografy. Praha (Universita Karlova, Fakulta prírodovědecká, SPN).

PETIT, C., KONOLD, W., HÖCHTL, F. (2012). Historic terraced vineyards: Impressive witnesses of vernacular architecture, Landscape History, 33, 5-28, DOI: https:// doi.org/10.1080/01433768.2012.671029.

POSCHLOD, P., BRAUN-REICHERT, R. (2017). Small natural features with large ecological roles in ancient agricultural landscapes of Central Europe - history, value, status, and conservation. Biological Conservation, 211, 60-68. DOI: https://doi.org/10.1016/ j.biocon.2016.12.016.

POSPÍŚILOVÁ, D., SEKERA, D., ŠIMORA, R. (2005). Zonalizácia vinohradníckeho katastra obce Modra. Geologická a pôdna charakteristika. Vinič a víno, 6, 139-141.

RIEZNER, J. (2007). Agrární formy reliéfu ve Zlatohorské vrchovině. Geomorfologia Slovaca and Bohémica, 1, 50-55.

RUSTERHOLZ, H. P., BINGGELI, D., BAUR, B. (2020). Successful restoration of abandoned terraced vineyards and grasslands in Southern Switzerland. Basic and Applied Ecology, 42, 35-46. DOI: https://doi.org/10.1016/j.baae.2019.07.002.

SERENI, E. (1961). Storia del paesaggio agrario italiano. Laterza (Collezione storica).

SLÁMOVÁ, M., BELČ́́KOVÁ, I. (2020). The vineyard landscapes. History and trends of viticulture in case studies from Slovakia. Pirineos, 175, 1-16. DOI: https://doi.org/ 10.3989/pirineos.2020.175006.

ŠÁLY, R. (1996). Pedológia. Zvolen (Technická univerzita).

ŚÁLY, R., ŠURINA, B. (2002). Pôdy. Mapa 1:500 000. Atlas krajiny Slovenskej republiky. Bratislava (Ministerstvo životného prostredia Slovenskej republiky, Esprit, s. r. o.).

ŠIMƯNEK, R. (2012). The landscape of the Czech middle ages in the perspective of modern science. Historická geografie, 38, 36-62.

ŠÍMOVÁ, M. et al. (1996). Miestny územný systém ekologickej stability Modra, [Online]. Available: https://m.modra.sk/miestny-uzemny-system-ekologickej-stability/d-1393 [Accessed 2 December 2020]. 
ŠPULEROVÁ, J., ŠTEFUNKOVÁ, D., DOBROVODSKÁ, M., et al. (2017). Historické štruktúry pol'nohospodárskej krajiny Slovenska. Bratislava (Veda).

ŠTEFUNKOVÁ, D., CEBECAUER, T. (2006). Visibility analysis as a part of landscape visual quality assessment. Ekológia (Bratislava), 25, suppl., 1, 229-239.

ŠTEFUNKOVÂ, D., DOBROVODSKA, M., KANKA, R., KRNÁČOVÁ, Z., BEZÁK, P., BOLTIŽIAR, M., DAVID, S., DRAMSTAD, W., DUGOVÁ, O., FJELLSTAD, W., GAJDOŠ, P., HALADA, L., HREŠKO, J., IZAKOVIČOVẢ, Z., KALIVODA, H., KALIVODOVÁ, E., KENDERESSY, P., KRIŠTÍN, A., MAJZLAN, O., MOYZEOVÁ, M., PETROVIČ, F., STAŠIOV, S., ŠTEFFEK, J., VAGAČOVÁ, M. (2011). Atraktivita malokarpatskej krajiny s dôrazom na historické agrárne štruktúry a biodiverzitu. Bratislava (Ústav krajinnej ekológie SAV). CD-ROM.

ŠTEFUNKOVÁ, D., HANUŠIN, J. (2019). Viticultural landscapes: Localised transformations over the past 150 years through an analysis of three case studies in Slovakia. Moravian Geographical Reports, 27, 155-168. DOI: https://doi.org/10.2478/mgr-20190012.

TAROLLI, P., PRETI, F., ROMANO, N. (2014). Terraced landscapes: From an old best practice to a potential hazard for soil degradation due to land abandonment. Anthropocene, 6, 10-25. DOI: https://doi.org/10.1016/j.ancene.2014.03.002.

THORSON, R. M. (2002). Stone by stone: The magnificent history in New England's stone walls. London (Bloomsbury Publishing).

THORSON, R. M. (2005). Exploring stone walls: A field guide to New England's stone walls. New York (Walker \& Company).

TURCSÁNY, J. (2006). Hospodárstvo. In Žudel, J., Dubovský, J. M., eds. Dejiny Modry. Modra (Mestský úrad Modra), pp. 327-341.

TURCSÁNY, J., ed. (2009). Svätý Jur 1209 - 2009. Dejiny písané vínom. Svätý Jur (Mesto Svätý Jur).

URBÁNEK, J. (2014). Malé Karpaty - príbeh pohoria. Bratislava (Veda).

VAROTTO, M., BONARDI, L., TAROLLI, P., eds. (2019). World terraced landscapes: History, environment, quality of life, environmental history. Cham (Springer). DOI: https://doi.org/10.1007/978-3-319-96815-5.

WEIBULL, A. C., ÖSTMAN, Ö., GRANQVIST, Á. (2003). Species richness in agroecosystems: The effect of landscape, habitat and farm management. Biodiversity \& Conservation, 12, 1335-1355. DOI: https://doi.org/10.1023/A:1023617117780.

Ján Ha nuši n, Dagmar Št efunková, Miloš Rus nák

\section{KAMENICE A KAMENNÉ MÚRIKY AKO RELIKT TRADIČNEJ VINOHRADNÍCKEJ KRAJINY (PRÍPADOVÁ ŠTÚDIA OKOLIE MODRY, SLOVENSKO)}

Akumulácie kamenia v krajine majú rôzny tvar, genézu, vek a určenie, pričom ich významná čast' sa viaže k pol'nohospodárskej krajine. Prebytočné kamene odstránené z pôdy počas obrábania boli ukladané na hranice pozemkov, kde v priebehu stáročí vznikali vol’ne uložené kopy (kamenice) alebo usporiadané útvary (kamenné múry), ktoré viditel'ne ohraničili pozemok.

Ciel'om príspevku je porovnávacia priestorová analýza rozloženia kameníc a kamenných múrov a ich charakteristík, interpretácia príčin ich zmien a základné typologické členenie v rokoch 1894 a 2018. Rozloženie prevažnej väčšiny kameníc a kamenných múrikov v roku 1894 sme nadobudli z máp stabilného katastra. Súčasný stav ich rozloženia sme získali z máp stabilného katastra, ktoré sme aktualizovali na základe máp 1:5000 z roku 2010, leteckých snímok z roku 2017 a terénnym výskumom, pri ktorom sme popri vizuálnej rekognoskácii zamerali koncové body dostupných kameníc pomocou GPS. Finálne spresnenie súčasného stavu sme urobili prostredníctvom lidarových dát. Pre každú z kameníc 
a kamenných múrikov sme stanovili plochu, dížku, maximálnu, minimálnu a priemernú nadmorskú výšku, rozdiel maximálnej a minimálnej nadmorskej výšky, priemerný sklon a priemerný aspekt. Na základe tvaru pôdorysu sme vyčlenili tri pôdorysné typy a polohu voči základným geomorfologickým jednotkám v zmysle práce Mazúra a Lukniša (1978) a vzhl’adom na základné geomorfologické tvary v zmysle práce Urbánka (2014). Objemy kameníc a kamenných múrikov sme vypočítali na základe rozdielu rastrov digitálneho modelu reliéfu (DTM) a DTMnull, vygenerovaných z klasifikovaného mračna bodov lidarových dát. Vzhl'adom na nesúlad tvaru reliéfu vo vel'kej časti študovaného územia v roku 1894 a v súčasnosti, ktorý je podmienený výstavbou terasovaných viníc a novou zástavbou, sme objem kameníc a kamenných múrikov v roku 1894 nehodnotili. Takto vypočítaný objem nezohl'adňuje ich prirodzenú porozitu (podiel priestoru nevyplneného kamením). Závislosti medzi jednotlivými charakteristikami (okrem pôdorysného typu) $\mathrm{v}$ dvoch sledovaných rokoch sme kvantifikovali korelačným koeficientom $r$ a koeficientom determinácie $\left(r^{2}\right)$.

Študované územie (707 ha) pokrýva juhozápadnú čast’ katastrálneho územia mesta Modra. Nadmorské výšky kolíšu medzi 153 - 373 m. Na celom území prevládajú žuly a im podobné horniny, na ktorých sa vytvorili slabo až stredne skeletnaté kambizeme. Územie je bez významných tokov, v mierne teplom a suchom podnebí spadne ročne priemerne 550 $600 \mathrm{~mm}$ zrážok. Vo vyvýšených polohách prevládajú zvyšky pôvodných dubovo-hrabových lesov, nižšie polohy zaberá prevažne vinohradnícka krajina s rôznou intenzitou využívania.

Kamenice a kamenné múriky sa koncentrovali v sklonených a členitých polohách s plytkými pôdami s vysokým obsahom skeletu. Kamenný materiál tvoria temer výlučne ostrohranné neopracované žulové bloky. Vzdialenosti medzi jednotlivými rovnobežnými kamenicami v areáloch s najvyššou hustotou sú zvyčajne $25-40 \mathrm{~m}$. Výška kameníc kolíše od niekol'ko desiatok $\mathrm{cm}$ po $4 \mathrm{~m}$, šírka $2-20 \mathrm{~m}$, dížka pretiahnutého jednoduchého typu kolíše od 5 po $460 \mathrm{~m}$. Kamenné múry majú výšku do $1,0-1,5 \mathrm{~m}$, šírku $1-5 \mathrm{~m}$ a symetrický prierez približne obdížnikového tvaru, ktorý je relatívne stály.

Získané výsledky poukazujú na významné zmeny v rozsahu, vel'kosti a tvare kameníc a kamenných múrikov $\mathrm{v}$ čase a $\mathrm{v}$ priestore. Výstavba terasovaných viníc a rozširovanie zástavby spôsobil ich zánik v nižších polohách na Podmalokarpatskej pahorkatine, kamenice a kamenné múriky vo vyšších a členitejších polohách na okraji pásma viníc a v lesoch (bývalých viniciach) sa výrazne nezmenili. V porovnaní s rokom 1894 poklesol počet kameníc a kamenných múrikov v roku 2018 o $38 \%$, celková rozloha o $62 \%$, priemerná rozloha o $40 \%$, priemerná dížka o $42 \%$, naopak narástla priemerná nadmorská výška (o $10 \%$ ) a priemerný sklon (o približne $20 \%$ ).

Kamenice a kamenné múriky zvyšujú biodiverzitu krajiny, sú svedkom vývoja tradičnej vinohradníckej krajiny s nezanedbatel'nou kultúrnohistorickou hodnotou, čo vytvára dostatočné dôvody, pre ktoré si prinajmenšom najlepšie zachovaná a najtypickejšia čast' územia s kamenicami zaslúži obnovu a ochranu.

Article first received: December 2020

Article accepted: February 2021 